\title{
Effect of Convalescent Plasma on Mortality among Hospitalized Patients with COVID-19: Initial Three- Month Experience
}

Michael J. Joyner ${ }^{1 \star}$, M.D., Jonathon W. Senefeld ${ }^{1}$, Ph.D., Stephen A. Klassen ${ }^{1}$, Ph.D., John R. Mills ${ }^{2}$, Ph.D., Patrick W. Johnson ${ }^{3}$, Elitza S. Theel' ${ }^{2}$, Ph.D., Chad C. Wiggins ${ }^{1}$, Ph.D., Katelyn A. Bruno ${ }^{4}$, Ph.D., Allan M. Klompas ${ }^{1}$, M.B., B.Ch., B.A.O., Elizabeth R. Lesser $^{3}$, Katie L. Kunze ${ }^{5}$, Ph.D., Matthew A. Sexton ${ }^{1}$, M.D., Juan C. Diaz Soto ${ }^{1}$, M.D., Sarah E. Baker ${ }^{1}$, Ph.D., John R.A. Shepherd', M.D., Noud van Helmond ${ }^{6}$, M.D., Nigel S. Paneth ${ }^{7,8 \#}$, M.D., M.P.H., Ph.D., DeLisa Fairweather ${ }^{4 \#}$, Ph.D., R. Scott Wright ${ }^{9,10 \#,}$ M.D., Rickey E. Carter ${ }^{3 \#}$, Ph.D., Arturo Casadevall ${ }^{11 \#}$, M.D., Ph.D., the US EAP COVID19 Plasma Consortium,

US EAP COVID-19 Plasma Consortium: Camille M. van Buskirk², M.D., Jeffrey L.

Winters $^{2}$, M.D., James R. Stubbs ${ }^{2}$, M.D., Robert F. Rea ${ }^{9}$, M.D, David O. Hodge ${ }^{3}$, Vitaly Herasevich ${ }^{1}$, M.D., Ph.D., Emily R. Whelan ${ }^{4}$, Andrew J. Clayburn ${ }^{1}$, Kathryn F. Larson ${ }^{9}$, M.D., Juan G. Ripol1', M.D., Kylie J. Andersen', Matthew R. Buras ${ }^{5}$, Matthew N.P. Vogt $^{1}$, M.D., Joshua J. Dennis ${ }^{1}$, Riley J. Regimbal ${ }^{1}$, Philippe R. Bauer ${ }^{12}$, M.D., Ph.D., and Janis E. Blair ${ }^{13}$, M.D.

Affiliations:

${ }^{1}$ Department of Anesthesiology and Perioperative Medicine, Mayo Clinic, Rochester, Minnesota ${ }^{2}$ Department of Laboratory Medicine and Pathology, Mayo Clinic, Rochester, Minnesota

${ }^{3}$ Department of Health Sciences Research, Mayo Clinic, Jacksonville, Florida

${ }^{4}$ Department of Cardiovascular Medicine, Mayo Clinic, Jacksonville, Florida

${ }^{5}$ Department of Health Sciences Research, Mayo Clinic, Scottsdale, Arizona

${ }^{6}$ Department of Anesthesiology, Cooper Medical School of Rowan University, Cooper University Health Care, Camden, New Jersey

${ }^{7}$ Department of Epidemiology and Biostatistics, College of Human Medicine, Michigan State

University, East Lansing, Michigan

${ }^{8}$ Department of Pediatrics and Human Development, College of Human Medicine, Michigan

State University, East Lansing, Michigan

${ }^{9}$ Department of Cardiovascular Medicine, Mayo Clinic, Rochester, Minnesota

${ }^{10}$ Human Research Protection Program, Mayo Clinic, Rochester, Minnesota

${ }^{11}$ Department of Molecular Microbiology and Immunology, Johns Hopkins Bloomberg School of Public Health, Baltimore, Maryland

${ }^{12}$ Department of Internal Medicine, Division of Pulmonary and Critical Care Medicine, Mayo Clinic, Rochester, Minnesota

${ }^{13}$ Department of Internal Medicine, Division of Infectious Diseases, Mayo Clinic, Phoenix, Arizona

\section{${ }^{\star}$ Correspondence:}

Michael J. Joyner, M.D., Department of Anesthesiology and Perioperative Medicine Mayo Clinic | 200 First Street SW | Rochester, MN 55905

41 \# Drs. Paneth, Fairweather, Wright, Carter and Casadevall contributed equally as senior authors 42 to the work of the study and manuscript. 


\section{Key Points}

44 Question. Does transfusion of human convalescent plasma reduce mortality among

45 hospitalized COVID-19 patients?

46 Findings. Transfusion of convalescent plasma with higher antibody levels to

47 hospitalized COVID-19 patients significantly reduced mortality compared to transfusions

48 with low antibody levels. Transfusions within three days of COVID-19 diagnosis yielded

49 greater reductions in mortality.

50 Meaning. Embedded in an Expanded Access Program providing access to COVID-19

51 convalescent plasma and designed to assess its safety, several signals consistent with

52 efficacy of convalescent plasma in the treatment of hospitalized COVID-19 patients

53 emerged. 


\section{Abstract}

55 Importance: Passive antibody transfer is a longstanding treatment strategy for 56 infectious diseases that involve the respiratory system. In this context, human 57 convalescent plasma has been used to treat coronavirus disease 2019 (COVID-19), but 58 the efficacy remains uncertain.

59 Objective: To explore potential signals of efficacy of COVID-19 convalescent plasma.

Design: Open-label, Expanded Access Program (EAP) for the treatment of COVID-19

61 patients with human convalescent plasma.

62 Setting: Multicenter, including 2,807 acute care facilities in the US and territories.

63 Participants: Adult participants enrolled and transfused under the purview of the US

64 Convalescent Plasma EAP program between April 4 and July 4, 2020 who were 65 hospitalized with (or at risk of) severe or life threatening acute COVID-19 respiratory syndrome.

Intervention: Transfusion of at least one unit of human COVID-19 convalescent plasma using standard transfusion guidelines at any time during hospitalization. Convalescent plasma was donated by recently-recovered COVID-19 survivors, and the antibody levels in the units collected were unknown at the time of transfusion.

Main Outcomes and Measures: Seven and thirty-day mortality.

Results: The 35,322 transfused patients had heterogeneous demographic and clinical characteristics. This cohort included a high proportion of critically-ill patients, with 52.3\% in the intensive care unit (ICU) and $27.5 \%$ receiving mechanical ventilation at the time of plasma transfusion. The seven-day mortality rate was $8.7 \%[95 \% \mathrm{Cl} 8.3 \%-9.2 \%]$ in patients transfused within 3 days of COVID-19 diagnosis but 11.9\% [11.4\%-12.2\%] in patients transfused 4 or more days after diagnosis $(p<0.001)$. Similar findings were observed in 30-day mortality (21.6\% vs. $26.7 \%$, p<0.0001). Importantly, a gradient of mortality was seen in relation to IgG antibody levels in the transfused plasma. For

80 patients who received high IgG plasma (>18.45 S/Co), seven-day mortality was $8.9 \%$

81 (6.8\%, 11.7\%); for recipients of medium IgG plasma (4.62 to $18.45 \mathrm{~S} / \mathrm{Co}$ ) mortality was $8211.6 \%(10.3 \%, 13.1 \%)$; and for recipients of low IgG plasma (<4.62 S/Co) mortality was 
$8313.7 \%(11.1 \%, 16.8 \%)(p=0.048)$. This unadjusted dose-response relationship with IgG 84 was also observed in thirty-day mortality $(p=0.021)$. The pooled relative risk of mortality 85 among patients transfused with high antibody level plasma units was 0.65 [0.47-0.92] 86 for 7 days and 0.77 [0.63-0.94] for 30 days compared to low antibody level plasma 87 units.

88 Conclusions and Relevance: The relationships between reduced mortality and both 89 earlier time to transfusion and higher antibody levels provide signatures of efficacy for 90 convalescent plasma in the treatment of hospitalized COVID-19 patients. This 91 information may be informative for the treatment of COVID-19 and design of 92 randomized clinical trials involving convalescent plasma.

93 Trial Registration: ClinicalTrials.gov Identifier: NCT04338360 
medRxiv preprint doi: https://doi.org/10.1101/2020.08.12.20169359; this version posted August 12, 2020. The copyright holder for this preprint (which was not certified by peer review) is the author/funder, who has granted medRxiv a license to display the preprint in perpetuity.

All rights reserved. No reuse allowed without permission.

94

95

96

97

98

99

100

101

102

103

104

105

106

107

108

109

110

111

112

113

114

115

116

117

118

\section{Introduction}

Passive antibody transfer, including convalescent plasma or serum, has previously been used to treat infectious diseases that involve the respiratory system ${ }^{1-3}$. This therapeutic approach was established early in the last century and included widespread use of convalescent plasma for treatment of the 1918 influenza ${ }^{4}$. In this context, the coronavirus disease 2019 (COVID-19) pandemic has revived interest in the use of convalescent plasma for the treatment of hospitalized patients with COVID-19. Although there is substantial interest in the use of COVID-19 convalescent plasma, the efficacy signals are preliminary ${ }^{5,6}$.

In response to the global COVID-19 pandemic and need for access to treatments possibly providing benefit while randomized clinical trials were in various stages of development and enrollment, the Mayo Clinic initiated the US Expanded Access Program (EAP) for convalescent plasma, which resulted in widespread use of convalescent plasma to treat COVID-19 in the U.S. The EAP received collaborative and financial support from the Biomedical Advanced Research and Development Authority (BARDA). Although the charter of the EAP was to provide access to and assess the safety of COVID-19 convalescent plasma, we performed exploratory analyses on the efficacy of this agent. We hypothesized, based on historical data that earlier administration of convalescent plasma with high antibody levels would be associated with reduced mortality. To address this hypothesis, we evaluated seven and 30-day mortality in 35,322 hospitalized adults transfused with COVID-19 convalescent plasma by asking two questions. First, was earlier treatment of patients with convalescent plasma after diagnosis of COVID-19 associated with reduced mortality compared to later treatment in the course of disease? Second, were higher antibody levels in the transfused convalescent plasma associated with reduced mortality? 


\section{Methods}

\section{Design and Oversight}

121 As described previously ${ }^{7,8}$, the EAP was a US Government-sponsored, national, 122 pragmatic intervention conducted as a multicenter, open-label protocol in hospitalized adults with COVID-19. All hospitals or acute care facilities in the US and any physician

124 licensed in the US were eligible to participate provided they agreed to adhere to the 125 treatment protocol, FDA, and state regulations.

126 Mayo Clinic served as the academic research organization conducting the study. The 127 Mayo Clinic Institutional Review Board (IRB) was the central IRB, approved the protocol 128 all modifications, and performed regulatory oversight for all sites and investigators. The 129 principal investigator served as the regulatory sponsor. A Data and Safety Monitoring 130 Board oversaw the safety analyses and advised the regulatory sponsor and the Mayo 131 Clinic IRB on risk. Written informed consent was obtained from the participant or a 132 legally-authorized representative prior to enrollment, except for those patients who 133 necessitated use of an emergency consent process defined in collaboration with the US 134 FDA.

\section{Participants}

136 Eligible patients were aged 18 years or older, hospitalized with a laboratory confirmed 137 diagnosis of infection with severe acute respiratory syndrome coronavirus 2 (SARS138 CoV-2), and had (or were judged by a healthcare provider to be at high risk of 139 progression to) severe or life-threatening COVID-19. Inclusion criteria and the clinical 140 symptoms defining severe or life-threatening COVID-19 are outlined in Supplement 1.

\section{Plasma Collection}

142 Convalescent plasma was obtained from a registered or licensed blood collector, and 143 COVID-19 antibody levels were unknown at the time of plasma collection. Convalescent 144 plasma was donated by COVID-19 survivors with confirmed diagnosis via clinical 145 laboratory test whom were symptom free for 14 days, or more according to standard 146 blood center procedures ${ }^{9}$. An aliquot of plasma or serum was shipped from a subset of 147 blood collection centers for later antibody testing. At the time of collection, each plasma 
medRxiv preprint doi: https://doi.org/10.1101/2020.08.12.20169359; this version posted August 12, 2020. The copyright holder for this preprint (which was not certified by peer review) is the author/funder, who has granted medRxiv a license to display the preprint in perpetuity.

All rights reserved. No reuse allowed without permission.

148 unit was assigned a standardized identifying number (ISBT 128 code) specific to the

149 donor, which was used to link antibody levels with study outcomes corresponding to the 150 plasma recipient(s).

\section{Plasma Transfusion}

152 Compatible COVID-19 convalescent plasma was administered intravenously according 153 to individual institutional protocols. The transfusion dose of COVID-19 convalescent 154 plasma was at least one unit (approximately $200 \mathrm{~mL}$ ), with the option to administer 155 additional doses if clinically justified.

\section{Data Entry}

157 Web-based, standardized data reporting surveys were completed to assess the clinical 158 status of patients using the Research Electronic Data Capture system (REDCap, 159 v.9.1.15 Vanderbilt University, Nashville, TN $)^{10,11}$, with FDA authorization, as previously 160 described $^{7,8}$. Given the rapidity at which the EAP was implemented and considering the 161 stress on clinical staff at participating sites during this on-going pandemic, the web162 based case reporting forms were designed to optimize convenience. Additionally, 163 although the patient inclusion criteria were specific to hospitalized patients, these 164 criteria were exceptionally broad (Supplement 1). While these elements of the EAP 165 may be atypical, they are perhaps understandable in a crisis of the magnitude of the 166 COVID 19 pandemic.

\section{Antibody testing}

168 Binding antibody levels from sera were tested using the Ortho-Clinical Diagnostics 169 VITROS Anti-SARS-CoV-2 IgG chemiluminescent immunoassay (CLIA) in accordance 170 with manufacturer instructions ${ }^{12}$. The Ortho-Clinical IgG CLIA is a qualitative assay 171 based on a recombinant form of the SARS-CoV-2 spike subunit 1 protein. Results of 172 this assay are based on the sample signal-to-cut-off (S/Co) ratio, with values $<1.0$ and $173 \geq 1.00$ corresponding to negative and positive results, The $\mathrm{S} / \mathrm{Co}$ values reflect relative 174 levels of anti-SARS-CoV-2 antibodies. 


\section{Statistics}

176 The sample size for the EAP was not determined a priori and patient accrual has not 177 concluded at the time of this writing. The sample sizes for these analyses varied by the 178 availability of linked antibody data, and in some cases, missing data. For the analyses 179 not associated with antibody data, all transfusions on or before July 4, 2020 were 180 included (i.e., three months after the first confirmed transfusion in the EAP). The 181 database was locked for this study report on August 5, 2020 to allow all included 182 patients to have up to 30 days of follow up after transfusion. For the subset of patients with remnant samples suitable for antibody analysis, all patients matched by the standardized identifying number (ISBT 128 code) were included, with some caveats

185 detailed below.

186 Based on insights from the pre-antibiotic era that antibody therapy was most effective when given early ${ }^{2,13}$, our cohort was stratified into categories based on the days from COVID-19 diagnosis to plasma transfusion, including: 0, 1-3, 4-10, and 11 or more days and for some graphical presentations and analyses, dichotomized into 0-3 vs. 4 or more days. The timing of death was recorded within the precision of a calendar day, so adjustments were needed to develop survival estimates. For deaths that occurred on

192 the same day of plasma transfusion, a death indicator representing 0.5 days was assigned. Otherwise, the number of days between plasma transfusion and death was calculated for each patient. Transfused patients were assumed to be alive unless death was recorded via web-based reporting survey.

Given that patients may have had more than one unit of plasma from different donors and the days from diagnosis to transfusion were heterogeneous, decision rules were required for analyses of the antibody data. To control for the potential confounding effects of plasma volume and non-uniform antibody levels between multiple plasma units in the analysis, plasma recipients with a single unit, defined as $150-250 \mathrm{~mL}$ of 201 plasma, were included in the analysis. Finally, plasma from a single donor may have 202 been fractioned into multiple plasma units and transfused to multiple recipients. The 203 analysis did not adjust for the potential clustering that may have occurred in doing so. 204 For the semi-quantitative Ortho-Clinical IgG assay, low, medium and high relative 
medRxiv preprint doi: https://doi.org/10.1101/2020.08.12.20169359; this version posted August 12, 2020. The copyright holder for this preprint (which was not certified by peer review) is the author/funder, who has granted medRxiv a license to display the preprint in perpetuity.

All rights reserved. No reuse allowed without permission.

205 binding antibody levels were established by setting thresholds for low and high based 206 on the $\sim 20^{\text {th }}$ and $\sim 80^{\text {th }}$ percentiles of the distribution for the S/Co ratios, respectively. 207 Accordingly, the thresholds were set at 4.62 S/Co and 18.45 S/Co.

208 Unadjusted (crude) mortality and adjusted mortality estimates were constructed. For the 209 unadjusted mortality, or case fatality rate, tabulations of the number of mortality events 210 recorded divided by the total number at risk were computed. Score confidence intervals 211 were estimated. For analysis within subgroups, crude mortality was also estimated by 212 grouping the events on key strata variables (e.g., time to transfusion; time epoch of the 213 study)

214 With the study being non-randomized and containing multiple sources of possible 215 confounding, adjusted estimates of point mortality were also estimated. Two 216 approaches to adjusting for confounding were implemented. First, the general process 217 of generating crude estimates by strata was used to estimate the relative risk by stratum 218 and then a pooled (common) estimate over all strata was estimated using the Mantel219 Haenszel estimator. The second approach for adjusted point estimates was developed 220 as an extension of the methods used for estimating adjusted survival, using a baseline 221 Cox regression model fitted to the data. Without loss of generality, we assumed a 222 single variable of direct interest (e.g., days to transfusion) and a set of covariates to be 223 controlled for within the estimate. Using the 'conditional' method for estimating adjusted 224 survival curves $^{14}$, an adjusted estimate of the mortality at Day 7, for example, was 225 obtained. To estimate the confidence interval for the adjusted survival curve, the 226 bootstrap method was used. For each of the bootstrap replicates, the original full data 227 set was used to determine the reference distribution for standardization of the mortality 228 estimate. This approach was extended to provide an estimate of the relative risk over 229 one or more variables of interest. The posterior distribution of potential relative risks was 230 constructed by a Cartesian merge of the posterior adjusted survival estimates for each 231 group. The $2.5^{\text {th }}$ and $97.5^{\text {th }}$ percentiles of this distribution were used as the bootstrap 232 confidence interval for the relative risk. No $p$-values were provided for this method. The 233 adjustment variables used in these analyses were as follows: time epoch (as shown in 234 Table 1), gender, race, age at enrollment (as categories), and indicator variables for 
235 having already developed one or more severe COVID-19 conditions (as shown in Table 236 1), being on a ventilator, use of hydroxychloroquine, use of remdesivir, and use of 237 steroids prior to transfusion.

238 Descriptive statistics are presented as frequencies and percentages. Analytic data are 239 presented as point estimates and 95\% confidence intervals. P-values less than 0.05 240 were considered statistically significant and no correction for multiple testing has been 241 applied to reported $p$-values. All statistical analyses were completed using $R$ version $242 \quad 3.6 .2$. 
medRxiv preprint doi: https://doi.org/10.1101/2020.08.12.20169359; this version posted August 12, 2020. The copyright holder for this preprint (which was not certified by peer review) is the author/funder, who has granted medRxiv a license to display the preprint in perpetuity.

Results

\section{Patient Characteristics}

245 Between April 4 and July 4, 2020, 47,047 patients were enrolled in the EAP, of whom 24636,226 were transfused with COVID-19 convalescent plasma. Of the 1,959 registered 247 sites with at least one patient enrolled, 1,809 sites had transfused at least one patient $248(92.3 \%)$ and 928 sites had transfused at least ten patients (47.4\%), Figure 1. Data were 249 included for 35,322 transfused patients with 7-day and 30-day follow-up. Key patient 250 characteristics are presented in Table 1, stratified into three groups delineating the time 251 period of the study and COVID-19 pandemic. The data set represented a non252 probability sample of hospitalized COVID-19 patients with diverse representation of 253 gender, age, weight status, race, and ethnicity. As shown in Table 1, the patients 254 transfused early in the study period (before May 01) were more critically-ill (higher rates 255 of mechanical ventilation, ICU admissions and septic shock), had higher concomitant 256 treatment with hydroxychloroquine and azithromycin, and lower concomitant treatment 257 with remdesivir compared with groups transfused later in the study period.

\section{Unadjusted Analyses}

259 Since the initiation of the EAP, there has been a reduction in both the seven-day crude 260 mortality rate and a pronounced shift of the time to transfusion towards more rapid 261 transfusion of convalescent plasma. The crude seven-day mortality rate was reduced in 262 patients transfused within 3 days (8.7\%, 8.3\%-9.2\%) of COVID-19 diagnosis compared 263 to patients transfused 4 or more days after COVID-19 diagnosis (11.9\%, 11.4\%-12.3\%; $264 P<0.001)$, Table 2. Similar trends were seen for unadjusted 30-day mortality. Table 2 265 presents several additional analyses by risk modifiers (e.g., age and ventilation status at 266 time of transfusion). As a means for controlling for study epoch, the time to transfusion 267 association is presented further stratified by study period. More favorable estimates for 268 mortality were found for all early transfusions (3 or fewer days) across both 7- and 30269 day mortality for all three study months $(P<0.001$; Table 2).

\section{Adjusted Analysis including Antibodies}

271 In a subset of 3,082 transfused patients who received only a single unit of plasma (150 $272-250 \mathrm{~mL}$ ), the unadjusted antibody association with mortality is presented in Table 2. 
273 Supplemental Table 2 presents the key demographic data by antibody groups (low, 274 medium and high) for these patients. While there were some statistically significant 275 differences among the antibody level groupings, this table shows that patients were well 276 balanced across the antibody level groupings as a whole. The associations of mortality 277 with antibody levels was found at both 7 - and 30-days ( $p<0.05$ for both) and when 278 antibody levels were stratified by time to transfusion, a pronounced separation in 279 mortality was found between the extremes of the classification (early transfusion, high 280 antibody levels vs. late transfusion, low antibody levels) albeit the associations for 7-day 281 mortality was at the threshold for statistical significance $(p=0.05)$. Supplemental Table 2822 presents additional estimates of crude mortality on the subset of patients with 283 matched antibody data.

284 Figure 2A presents the adjusted analyses with antibody groupings alone whereas 285 Figure 2B presents these same data allowing for the timing of the transfusion to be integrated directly into the analysis. These data demonstrate a clear "dose" dependent relationship of reduced 7-day mortality with the higher antibody levels. Figure $\mathbf{2 C}$ and 2D replicate these findings using 30-day mortality data. While some confidence intervals include the null value of relative risk of 1.0 , the magnitude of relative risks, particularly after adjustment, is an important finding of the study.

291 Figure 3 presents an alternate analytical approach to estimate the effect of the antibody levels. The stratified Mantel-Haenszel approach estimates the relative risk for both 7and 30-day mortality for patient profiles in the analysis. This stratification approach 294 provides direct analytical control for the potential confounders as each row in the figure represents homogeneity with respect to the factors listed. Overall, there is a consistent 296 signal of a protective effect of the high antibody levels across the strata. The pooled, or 297 common, relative risk for 7 -day and 30-day mortality were 0.65 (0.47 to 0.92 ) and 0.77 298 (0.63 to 0.94). For this analysis only patients transfused with units containing antibody 299 levels over $18.45 \mathrm{~S} / \mathrm{Co}$ or less than $4.62 \mathrm{~S} / \mathrm{Co}$ were included. 


\section{Discussion}

301 In our cohort of over 35,000 hospitalized patients with COVID-19, several signals 302 consistent with effectiveness for convalescent plasma were observed in a broad sample 303 of acute care facilities across the US. Earlier use of convalescent plasma was 304 associated with lower observed rates of 7-day and 30-day mortality. The use of 305 convalescent plasma with higher antibody levels was associated with reduced 7-day 306 and 30-day mortality. These findings were supported by two different analytical methods 307 used to control for confounding. The finding of a dose response between antibody levels 308 and reduction in mortality provides strong evidence that specific antibody is the active 309 agent in convalescent plasma for treatment of COVID-19. All data considered as a 310 whole, these findings are consistent with the notion that the quality and manner in which 311 convalescent plasma is administered to patients hospitalized with COVID-19 may 312 reduce mortality.

313 Given the historical efficacy of passive antibody therapy for infectious diseases, the 314 primary objective of the EAP was to facilitate access to convalescent plasma for 315 hospitalized COVID-19 patients across the US. The other major goal was to assess 316 safety. With these goals met $^{7,8}$, we analyzed the data from 1,809 sites and noted there 317 was variability in time to transfusion after diagnosis. Initially, we had no information 318 about the antibody levels in the convalescent plasma being administered. These 319 factors provided elements of inherent randomization in the data collected and formed 320 the basis of an exploratory analysis for signals associated to efficacy. They are also 321 consistent with key principles of antibody therapy recognized during the heyday of this 322 treatment modality in the 1920 s and $30 s^{15,16}$, supporting their use as a framework to 323 explore the efficacy of convalescent plasma in COVID-19.

\section{Time to Treatment}

325 Both 7-day and 30-day mortality adjusted for disease severity and demographic factors 326 were reduced in patients transfused within 3 days of COVID-19 diagnosis compared to 327 patients transfused 4 or more days after COVID-19 diagnosis. Additionally, the declining week-to-week trends in crude mortality (as previously observed ${ }^{7}$ ) were temporally associated with more rapid treatment. Prior to the antibiotic era, treatment of respiratory 
medRxiv preprint doi: https://doi.org/10.1101/2020.08.12.20169359; this version posted August 12, 2020. The copyright holder for this preprint (which was not certified by peer review) is the author/funder, who has granted medRxiv a license to display the preprint in perpetuity.

All rights reserved. No reuse allowed without permission.

330 infections with antibody therapy was most effective if initiated within three days of 331 hospitalization. Thus, we used a similar timeframe, relative to date of diagnosis rather 332 than hospitalization, for stratifying the current data. Along similar lines, 7 and 30 day 333 survivors received on average higher volumes of plasma in unadjusted analyses. This is 334 of interest because we had no knowledge of the volume of plasma which might constitute an efficacious dose prior to beginning this study.

\section{Antibody Assessment}

337 Seven and 30 day mortality rates were reduced in patients who received plasma with higher antibody levels. This finding is more limited than the time data as only a subset of the plasma units had remnant samples preserved that were suitable for assaying antibody levels. The survival benefit became more pronounced when the analysis was restricted to less severely ill patients treated early. Because of the multifactorial nature of antibody-mediated effects and the potential for other disease modifying factors to be present in convalescent plasma, further assay development to more fully characterize

344 the mechanisms in which plasma confers anti-viral properties is warranted. We also note that there was no evidence of worsening outcomes or increased mortality in patients treated with very high antibody levels indicating that antibody dependent enhancement of disease was unlikely. Finally, it is important to recognize that the antibody levels we obtained were on repurposed remnant biospecimens collected for blood banking quality assurance. Thus there was potential variability in a number of

350 factors related to biospecimen handling and storage that might influence the measurement of antibody levels in the specimens available to us. Of note adjusted 30day mortality was $30 \%$ in patients treated with plasma with low antibody levels (IgG) 4 or more days after COVID-19 diagnosis. By contrast 30-day mortality was $20 \%$ in

354 patients treated within 3 days of diagnosis with plasma with high antibody levels. The 355 pooled estimate from the stratified analysis estimated a $23 \%$ relative reduction in 356 mortality at 30 days across a wide range of sub-strata within the study. This reduction in 357 mortality is similar to that observed in a number of small randomized trials and retrospective matched control studies ${ }^{17}$. 
medRxiv preprint doi: https://doi.org/10.1101/2020.08.12.20169359; this version posted August 12, 2020. The copyright holder for this preprint (which was not certified by peer review) is the author/funder, who has granted medRxiv a license to display the preprint in perpetuity. All rights reserved. No reuse allowed without permission.

\section{Limitations}

360 The design of the EAP has been criticized because it was not a randomized placebo, controlled trial $(\mathrm{RCT})^{18}$. We started the EAP in late March 2020. It was designed to provide access to convalescent plasma largely at hospitals and acute care facilities that were not already part of a RCT or did not have the infrastructure to support complex RCTs. We also envisioned modest total enrollment and our original IRB approval was for 5,000 patients. In this context, our primary goal was to report on the safety of convalescent plasma and to perform an exploratory analysis for potential signals of efficacy. As described earlier, the EAP was a pragmatic study design, organized to allow routine clinical care to dictate the timing and administration of plasma with the collection of real world data. We did not prespecify which medications patients should be on to participate. The enrollment and data collection forms were streamlined to make participation easy for sites engulfed in the work of a pandemic. The use of a central, academic IRB allowed for consistent data evaluation and oversight. We streamlined PI credentialing and IRB reliance processes. All forms were web-based at a time when some believed that SARS-CoV-2 might be transmitted via paper contaminated with the virus. We did not randomly assign treatment strategies or use of adjunctive medications. Nonetheless, there were some elements of randomization or pseudo-randomization in our study. Physicians could choose the timing of convalescent plasma, the number of units administered, any repeat therapies and whether ICU or mechanically ventilated patients were included. Furthermore, the degree of immune activity within the units of convalescent plasma (i.e. specific lgG levels) was not known. It was assumed that patients would receive plasma with low, medium and high antibody levels in a pseudorandomized manner and that would enable assessment of efficacy.

We acknowledge that RCTs produce evidence of the highest quality in most but not all clinical situations. RCTs can occur when a number of specific criteria are present which allow their conduct. First, RCTs necessitate a stable supply of investigational product (i.e. convalescent plasma) or placebo/comparator which can be pre-positioned at all participating sites. The supply of convalescent plasma in April was not sufficient for such collection and pre-positioning. Second, RCTs require sufficient numbers of sites which have an appropriate patient base to approach for the study. The COVID-19 
390 pandemic has migrated across different US regions every few weeks, making it 391 challenging to predict where sites should be selected and prepared for a RCT. Third, 392 sites must be validated and activated. This work requires training of the investigators 393 and study team members as well as typically on-site visits. The crises of the COVID-19 394 pandemic were not compatible with these site training and activation activities; travel within the US has been restricted and staff sent to activate sites would likely have been quarantined for two weeks before being able to go to another region to activate sites. Fourth, the very nature of a RCT requires subject willingness to be randomized to active treatment or placebo or a comparator agent. There was no consensus in April nor is there a global consensus now regarding what would be an appropriate placebo-control

400 to use. Fifth, many COVID-19 patients would likely have been distrustful of being 401 randomized to a placebo based upon historical precedent. Sixth, the number of sites 402 who could have participated in a RCT is limited; who was the appropriate ethical entity 403 to pick those sites and to exclude other sites? Our design allowed any willing hospital, $404 \mathrm{PI}$ and patient to be included in the pragmatic, real-world data study. Finally, there were ongoing small RCTs when we started this program. Physicians, hospitals and patients 406 have the choices of this program versus a RCT. It is clear that over 90,000 patients and 407 over 10,000 physicians elected to participate in the pragmatic, real-world evidence 408 study design. We did not indicate our study would prove efficacy or even offer potential 409 help. It was clear that it was a research investigation and informed consent was 410 obtained in all subjects prior to the transfusion of plasma. Perhaps the current design 411 can inform trialists and RCT advocates of the importance of study designs which are 412 easy and simple to join/enroll and which make the workload of participation as easy and 413 clinically relevant as possible.

\section{Conclusion}

415 The relationships between mortality and both time to plasma transfusion, and antibody 416 levels provide a signature that is consistent with efficacy for the use of convalescent 417 plasma in the treatment of hospitalized COVID-19 patients. 
medRxiv preprint doi: https://doi.org/10.1101/2020.08.12.20169359; this version posted August 12, 2020. The copyright holder for this preprint (which was not certified by peer review) is the author/funder, who has granted medRxiv a license to display the preprint in perpetuity.

All rights reserved. No reuse allowed without permission.

\section{Disclaimer}

419 The views and opinions expressed in this manuscript are those of the authors and do 420 not reflect the official policy or position of the US Department of Health and Human 421 services and its agencies including the Biomedical Research and Development 422 Authority and the Food and Drug Administration, as well as any agency of the U.S. 423 government. Assumptions made within and interpretations from the analysis are not 424 reflective of the position of any US government entity. 
medRxiv preprint doi: https://doi.org/10.1101/2020.08.12.20169359; this version posted August 12, 2020. The copyright holder for this preprint (which was not certified by peer review) is the author/funder, who has granted medRxiv a license to display the preprint in perpetuity. All rights reserved. No reuse allowed without permission.

Acknowledgements: We thank the dedicated members of the US Convalescent Plasma Expanded Access Program team- Machiko Anderson, Supriya Behl, Lori Bergstrom, Zachary Buchholtz, Brian Butterfield, Isha Chekuri, Joshua Culberson, Grant Dubbels, Adam Eggert, Ree Erickson, Rebekah Frost, Daniel Gaz, Winston Guo, Starr Guzman, Karina Hex, Vidhu Joshi, Megan Knudson, Tessa Kroeninger, Frances Lynch, Tim Miksch, Lisa Muenkel, Ryan Oldenburg, Amy Olofson, Laura Pacheco-Spann, Dr. Kelly Paulson, Dr. Sumedha Penheiter, Melanie Peterson, Katrina Pierce, Michaela Pletsch, Nicloas Saikali, Jeffrey Schmoll, Pamela Skaran, Lindsay Stromback, Edward Swaray, Morgan Swope, Kristine Tree, Joe Wick, Janelle Worthington. We thank the members of the Mayo Clinic Institutional Review Board, the Mayo Clinic Office of Human Research Protection, the Mayo Clinic Office of Research Regulatory support and in particular Mark Wentworth, the Executive Dean of Research at Mayo Clinic Dr. Gregory Gores and the CEO of Mayo Clinic Dr. Gianrico Farrugia for their support and assistance, and the independent Data and Safety Monitoring Board for their work and oversight of the Expanded Access Program- Dr. Allan S. Jaffe (chair), Dr. David O. Warner, Dr. William G. Morice II, Dr. Paula J. Santrach, Dr. Robert L. Frye, Dr. Lawrence J Appel, Dr. Taimur Sher. We thank the members of the National COVID-19 Convalescent Plasma Project (http://ccpp19.org) for their intellectual contributions and support. We thank the participating medical centers and medical teams, and blood centers for their rigorous efforts necessary to make this program possible. We also thank the donors for providing COVID-19 convalescent plasma.

Contract and Grant Support: This project has been funded in part with Federal funds from the Department of Health and Human Services; Office of the Assistant Secretary for Preparedness and Response; Biomedical Advanced Research and Development Authority under Contract No. 75A50120C00096. Additionally, this study was supported in part by National Center for Advancing Translational Sciences (NCATS) grant UL1TR002377, National Heart, Lung, and Blood Institute (NHLBI) grant 5R35HL139854 (to MJJ), National Institute of Diabetes and Digestive and Kidney Diseases (NIDDK) 5T32DK07352 (to JWS and CCW), Natural Sciences and Engineering Research Council of Canada (NSERC) PDF-532926-2019 (to SAK), National Institute of Allergy and Infectious Disease (NIAID) grants R21 Al145356, R21 Al152318 and R21 Al154927 (to DF), R01 Al152078 9 (to AC), National Heart Lung and Blood Institute R01 HL059842 (to AC), National Institute on Aging (NIA) U54AG044170 (to SEB), Schwab Charitable Fund (Eric E Schmidt, Wendy Schmidt donors), United Health Group, National Basketball Association (NBA), Millennium Pharmaceuticals, Octapharma USA, Inc, and the Mayo Clinic. 
medRxiv preprint doi: https://doi.org/10.1101/2020.08.12.20169359; this version posted August 12, 2020. The copyright holder for this preprint (which was not certified by peer review) is the author/funder, who has granted medRxiv a license to display the preprint in perpetuity. All rights reserved. No reuse allowed without permission.

\section{References}

1. Luke TC, Casadevall A, Watowich SJ, Hoffman SL, Beigel JH, Burgess TH. Hark back: passive immunotherapy for influenza and other serious infections. Crit Care Med. 2010;38(4 Suppl):e66-73.

2. Casadevall A, Scharff MD. Serum therapy revisited: animal models of infection and development of passive antibody therapy. Antimicrob Agents Chemother. 1994;38(8):1695-1702.

3. Casadevall A, Scharff MD. Return to the past: the case for antibody-based therapies in infectious diseases. Clin Infect Dis. 1995;21(1):150-161.

4. Luke TC, Kilbane EM, Jackson JL, Hoffman SL. Meta-analysis: convalescent blood products for Spanish influenza pneumonia: a future H5N1 treatment? Ann Intern Med. 2006;145(8):599-609.

5. Li L, Zhang W, Hu Y, et al. Effect of Convalescent Plasma Therapy on Time to Clinical Improvement in Patients With Severe and Life-threatening COVID-19: A Randomized Clinical Trial. JAMA. 2020.

6. Salazar E, Perez KK, Ashraf M, et al. Treatment of Coronavirus Disease 2019 (COVID19) Patients with Convalescent Plasma. Am J Pathol. 2020.

7. Joyner MJ, Bruno KA, Klassen SA, et al. Safety Update: COVID-19 Convalescent Plasma in 20,000 Hospitalized Patients. Mayo Clinic Proceedings. 2020;in press.

8. Joyner MJ, Wright RS, Fairweather D, et al. Early safety indicators of COVID-19 convalescent plasma in 5000 patients. $J$ Clin Invest. 2020.

9. Bloch EM, Shoham S, Casadevall A, et al. Deployment of convalescent plasma for the prevention and treatment of COVID-19. J Clin Invest. 2020.

10. Harris PA, Taylor R, Minor BL, et al. The REDCap consortium: Building an international community of software platform partners. J Biomed Inform. 2019;95:103208.

11. Harris PA, Taylor R, Thielke R, Payne J, Gonzalez N, Conde JG. Research electronic data capture (REDCap)--a metadata-driven methodology and workflow process for providing translational research informatics support. J Biomed Inform. 2009;42(2):377381.

12. Theel ES, Harring J, Hilgart H, Granger D. Performance Characteristics of Four HighThroughput Immunoassays for Detection of IgG Antibodies against SARS-CoV-2. J Clin Microbiol. 2020;58(8).

13. Flexner S. The Results of the Serum Treatment in Thirteen Hundred Cases of Epidemic Meningitis. J Exp Med. 1913;17(5):553-576.

14. Therneau TM, Crowson CS, Atkinson EJ. Adjusted survival curves. In: January; 2015.

15. Casadevall A, Scharff MD. "Serum Therapy" revisited: Animal models of infection and the development of passive antibody therapy. Antimicrob Agents Chemotherap. 1994;38:1695-1702.

16. Casadevall A, Scharff MD. Return to the past: the case for antibody-based therapies in infectious diseases. Clin Infect Dis. 1995;21:150-161.

17. Joyner MJ, Klassen SA, Senefeld JW, et al. Evidence favouring the efficacy of convalescent plasma for COVID-19 therapy in review. 2020.

18. Califf RM, Hernandez AF, Landray M. Weighing the Benefits and Risks of Proliferating Observational Treatment Assessments: Observational Cacophony, Randomized Harmony. JAMA. 2020. 
medRxiv preprint doi: https://doi.org/10.1101/2020.08.12.20169359; this version posted August $12,2020$. The copyright holder for this preprint (which was not certified by peer review) is the author/funder, who has granted medRxiv a license to display the preprint in perpetuity.

All rights reserved. No reuse allowed without permission.

\begin{tabular}{|c|c|c|c|c|c|}
\hline & $\begin{array}{c}\text { Apr } 04 \text { - May } 01 \\
(\mathrm{~N}=6,990)\end{array}$ & $\begin{array}{c}\text { May } 01-\text { Jun } 04 \\
(N=14,846)\end{array}$ & $\begin{array}{c}\text { Jun } 04 \text { - Jul } 04 \\
(N=13,486)\end{array}$ & $\begin{array}{c}\text { Total Patients } \\
(\mathrm{N}=35,322)\end{array}$ & $P$ value \\
\hline Age at Enrollment (years) & & & & & $<0.001$ \\
\hline 18 to 39 & $539(7.7 \%)$ & $1,337(9.0 \%)$ & $1,596(11.8 \%)$ & $3,472(9.8 \%)$ & \\
\hline 40 to 59 & $2,424(34.7 \%)$ & $4,938(33.3 \%)$ & $4,806(35.6 \%)$ & $12,168(34.4 \%)$ & \\
\hline 60 to 69 & $2,007(28.7 \%)$ & $3,791(25.5 \%)$ & $3,170(23.5 \%)$ & $8,968(25.4 \%)$ & \\
\hline 70 to 79 & $1,358(19.4 \%)$ & $2,879(19.4 \%)$ & 2,467 (18.3\%) & $6,704(19.0 \%)$ & \\
\hline 80 or older & $662(9.5 \%)$ & $1,901(12.8 \%)$ & $1,447(10.7 \%)$ & $4,010(11.4 \%)$ & \\
\hline Gender & & & & & $<0.001$ \\
\hline Female & $2,546(36.5 \%)$ & $5,961(40.2 \%)$ & $5,489(40.8 \%)$ & $13,996(39.7 \%)$ & \\
\hline Male & $4,416(63.4 \%)$ & $8,838(59.7 \%)$ & 7,961 (59.1\%) & $21,215(60.2 \%)$ & \\
\hline Undisclosed & $6(0.1 \%)$ & $11(0.1 \%)$ & $11(0.1 \%)$ & $28(0.1 \%)$ & \\
\hline Weight Status & & & & & $<0.001$ \\
\hline Underweight & $69(1.2 \%)$ & $286(1.9 \%)$ & $156(1.2 \%)$ & $511(1.5 \%)$ & \\
\hline Normal Weight & $1,010(17.4 \%)$ & $2,601(17.6 \%)$ & $1,744(12.9 \%)$ & $5,355(15.7 \%)$ & \\
\hline Overweight & $1,723(29.7 \%)$ & $4,096(27.8 \%)$ & $3,647(27.1 \%)$ & $9,466(27.8 \%)$ & \\
\hline Obese & $2,997(51.7 \%)$ & $7,761(52.6 \%)$ & $7,926(58.8 \%)$ & $18,684(54.9 \%)$ & \\
\hline Race & & & & & $<0.001$ \\
\hline White & $3,330(47.6 \%)$ & $7,299(49.2 \%)$ & $7,178(53.2 \%)$ & $17,807(50.4 \%)$ & \\
\hline Asian & $456(6.5 \%)$ & $628(4.2 \%)$ & $390(2.9 \%)$ & $1,474(4.2 \%)$ & \\
\hline $\begin{array}{l}\text { Black or African } \\
\text { American }\end{array}$ & $1,301(18.6 \%)$ & $2,971(20.0 \%)$ & 2,379 (17.6\%) & $6,651(18.8 \%)$ & \\
\hline Other or Unknown & $1,903(27.2 \%)$ & $3,948(26.6 \%)$ & $3,539(26.2 \%)$ & $9,390(26.6 \%)$ & \\
\hline Ethnicity & & & & & $<0.001$ \\
\hline Hispanic/Latino & $2,391(34.2 \%)$ & $5,297(35.7 \%)$ & $5,875(43.6 \%)$ & $13,563(38.4 \%)$ & \\
\hline Not Hispanic/Latino & $4,599(65.8 \%)$ & $9,549(64.3 \%)$ & $7,611(56.4 \%)$ & $21,759(61.6 \%)$ & \\
\hline \multicolumn{6}{|l|}{ Clinical Status } \\
\hline $\begin{array}{l}\text { Current severe or life- } \\
\text { threatening COVID-19 }\end{array}$ & $5,584(79.9 \%)$ & $9,761(65.7 \%)$ & 8,157 (60.5\%) & $23,502(66.5 \%)$ & $<0.001$ \\
\hline $\begin{array}{l}\text { Intensive Care Unit } \\
\text { (ICU) care prior to } \\
\text { infusion }\end{array}$ & $4,601(65.8 \%)$ & 7,908 (53.3\%) & $5,952(44.1 \%)$ & $18,461(52.3 \%)$ & $<0.001$ \\
\hline $\begin{array}{l}\text { Mechanical Ventilation } \\
\text { prior to infusion }\end{array}$ & $3,217(49.9 \%)$ & $4,143(27.9 \%)$ & $2,213(16.4 \%)$ & $9,573(27.5 \%)$ & $<0.001$ \\
\hline \multicolumn{6}{|l|}{ Severe Risk Factors ${ }^{\mathrm{a}}$} \\
\hline Respiratory failure & $4,063(72.8 \%)$ & $6,352(65.1 \%)$ & $4,760(58.4 \%)$ & $15,175(64.6 \%)$ & $<0.001$ \\
\hline Dyspnea & $3,543(63.4 \%)$ & $6,976(71.5 \%)$ & $6,476(79.4 \%)$ & $16,995(72.3 \%)$ & $<0.001$ \\
\hline $\begin{array}{l}\text { Blood oxygen saturation } \\
\leq 93 \%\end{array}$ & $3,507(62.8 \%)$ & $7,063(72.4 \%)$ & 6,394 (78.4\%) & $16,964(72.2 \%)$ & $<0.001$ \\
\hline $\begin{array}{l}\text { Lung infiltrates }>50 \% \\
\text { within } 24 \text { to } 48 \text { hours }\end{array}$ & $2,415(43.2 \%)$ & $4,151(42.5 \%)$ & $3,015(37.0 \%)$ & $9,581(40.8 \%)$ & $<0.001$ \\
\hline $\begin{array}{l}\text { Respiratory frequency } \geq \\
30 / \mathrm{min}\end{array}$ & $2,205(39.5 \%)$ & $4,174(42.8 \%)$ & $3,366(41.3 \%)$ & $9,745(41.5 \%)$ & $<0.001$ \\
\hline $\mathrm{PaO2}: \mathrm{FiO} 2$ ratio $<300$ & $1,905(34.1 \%)$ & $3,075(31.5 \%)$ & $1,952(23.9 \%)$ & $6,932(29.5 \%)$ & $<0.001$ \\
\hline $\begin{array}{l}\text { Multiple organ } \\
\text { dysfunction or failure }\end{array}$ & $1,062(19.0 \%)$ & $1,200(12.3 \%)$ & $560(6.9 \%)$ & $2,822(12.0 \%)$ & $<0.001$ \\
\hline Septic shock & $844(15.1 \%)$ & $960(9.8 \%)$ & $475(5.8 \%)$ & $2,279(9.7 \%)$ & $<0.001$ \\
\hline $\begin{array}{l}\text { Number of Severe Risk } \\
\text { Factors }\end{array}$ & & & & & $<0.001$ \\
\hline None & $1,407(20.1 \%)$ & $5,085(34.3 \%)$ & $5,331(39.5 \%)$ & $11,823(33.5 \%)$ & \\
\hline Limited (1 to 4$)$ & $3,895(55.7 \%)$ & $6,992(47.1 \%)$ & $6,190(45.9 \%)$ & 17,077 (48.3\%) & \\
\hline Many (5+) & $1,688(24.1 \%)$ & $2,769(18.7 \%)$ & $1,965(14.6 \%)$ & $6,422(18.2 \%)$ & \\
\hline
\end{tabular}


medRxiv preprint doi: https://doi.org/10.1101/2020.08.12.20169359; this version posted August 12, 2020. The copyright holder for this preprint (which was not certified by peer review) is the author/funder, who has granted medRxiv a license to display the preprint in perpetuity.

All rights reserved. No reuse allowed without permission.

\begin{tabular}{|c|c|c|c|c|c|}
\hline & $\begin{array}{l}\text { Apr } 04 \text { - May } 01 \\
\quad(N=6,990)\end{array}$ & $\begin{array}{l}\text { May } 01-\text { Jun } 04 \\
(N=14,846)\end{array}$ & $\begin{array}{c}\text { Jun } 04-\text { Jul } 04 \\
(N=13,486)\end{array}$ & $\begin{array}{l}\text { Total Patients } \\
(\mathrm{N}=35,322)\end{array}$ & $P$ value \\
\hline \multicolumn{6}{|l|}{$\begin{array}{l}\text { Medications during hospital } \\
\text { stay }\end{array}$} \\
\hline $\begin{array}{l}\text { Angiotensin Receptor } \\
\text { Blocker }\end{array}$ & $397(5.7 \%)$ & $839(5.7 \%)$ & $779(5.8 \%)$ & $2,015(5.7 \%)$ & 0.90 \\
\hline Ace Inhibitor & $467(6.7 \%)$ & $1,130(7.6 \%)$ & $1,023(7.6 \%)$ & $2,620(7.4 \%)$ & 0.032 \\
\hline Azithromycin & $3,811(54.5 \%)$ & $5,717(38.5 \%)$ & $5,456(40.5 \%)$ & $14,984(42.4 \%)$ & $<0.001$ \\
\hline Remdesivir & $329(4.7 \%)$ & $4,066(27.4 \%)$ & $6,240(46.3 \%)$ & $10,635(30.1 \%)$ & $<0.001$ \\
\hline Steroids & $3,736(53.4 \%)$ & $6,137(41.3 \%)$ & $7,735(57.4 \%)$ & $17,608(49.8 \%)$ & $<0.001$ \\
\hline Chloroquine & $33(0.5 \%)$ & $22(0.1 \%)$ & $6(0.0 \%)$ & $61(0.2 \%)$ & $<0.001$ \\
\hline Hydroxychloroquine & $4,356(62.3 \%)$ & $2,437(16.4 \%)$ & $245(1.8 \%)$ & $7,038(19.9 \%)$ & $<0.001$ \\
\hline Time to Transfusion & & & & & $<0.001$ \\
\hline 0 days & $141(2.0 \%)$ & $598(4.0 \%)$ & $625(4.6 \%)$ & $1,364(3.9 \%)$ & \\
\hline 1 to 3 days & $1,590(22.7 \%)$ & $5,748(38.7 \%)$ & $6,705(49.7 \%)$ & $14,043(39.8 \%)$ & \\
\hline 4 to 10 days & $2,843(40.7 \%)$ & $6,244(42.1 \%)$ & $5,271(39.1 \%)$ & $14,358(40.6 \%)$ & \\
\hline $11+$ days & $2,416(34.6 \%)$ & $2,256(15.2 \%)$ & $885(6.6 \%)$ & $5,557(15.7 \%)$ & \\
\hline
\end{tabular}


medRxiv preprint doi: https://doi.org/10.1101/2020.08.12.20169359; this version posted August 12, 2020. The copyright holder for this preprint (which was not certified by peer review) is the author/funder, who has granted medRxiv a license to display the preprint in perpetuity.

All rights reserved. No reuse allowed without permission.

Table 2. Crude Mortality (7 and 30 day) of patients transfused with COVID-10 Convalescent Plasma.

\begin{tabular}{|c|c|c|c|c|c|c|c|c|}
\hline & \multicolumn{4}{|c|}{ Seven-day Mortality } & \multicolumn{4}{|c|}{ Thirty-day Mortality } \\
\hline & Sample, No & $\begin{array}{c}\text { Events, } \\
\text { No }\end{array}$ & Estimate, $95 \% \mathrm{Cl}$ & P-value & Sample, No & $\begin{array}{l}\text { Events, } \\
\text { No }\end{array}$ & Estimate, $95 \% \mathrm{Cl}$ & P-value \\
\hline Overall Mortality & 35,322 & 3,706 & $10.5 \%(10.2 \%, 10.8 \%)$ & & 35,322 & 8,652 & $24.5 \%(24.0 \%, 24.9 \%)$ & \\
\hline Age & & & & $<0.0001$ & & & & $<0.0001$ \\
\hline $18-39 y$ & 3,472 & 109 & $3.1 \%(2.6 \%, 3.8 \%)$ & & 3,472 & 261 & $7.5 \%(6.7 \%, 8.4 \%)$ & \\
\hline $40-59 y$ & 12,168 & 662 & $5.4 \%(5.1 \%, 5.9 \%)$ & & 12,168 & 1,837 & $15.1 \%(14.5 \%, 15.7 \%)$ & \\
\hline $60-69 y$ & 8,968 & 897 & $10.0 \%(9.4 \%, 10.6 \%)$ & & 8,968 & 2,431 & $27.1 \%(26.2 \%, 28.0 \%)$ & \\
\hline $70-79 y$ & 6,704 & 1,023 & $15.3 \%(14.4 \%, 16.1 \%)$ & & 6,704 & 2,367 & $35.3 \%(34.2 \%, 36.5 \%)$ & \\
\hline 80 y or older & 4,010 & 1,015 & $25.3 \%(24.0 \%, 26.7 \%)$ & & 4,010 & 1,756 & $43.8 \%(42.3 \%, 45.3 \%)$ & \\
\hline On Ventilator Prior to Infusion & & & & $<0.0001$ & & & & $<0.0001$ \\
\hline No & 25,205 & 1,932 & $7.7 \%(7.3 \%, 8.0 \%)$ & & 25,205 & 4,523 & $17.9 \%(17.5 \%, 18.4 \%)$ & \\
\hline Yes & 9,573 & 1,685 & $17.6 \%(16.9 \%, 18.4 \%)$ & & 9,573 & 3,924 & $41.0 \%(40.0 \%, 42.0 \%)$ & \\
\hline Missing & 544 & 89 & $16.4 \%(13.5 \%, 19.7 \%)$ & & 544 & 205 & $37.7 \%(33.7 \%, 41.8 \%)$ & \\
\hline Days to Transfusion & & & & $<0.0001$ & & & & $<0.0001$ \\
\hline$<=3$ days & 15,407 & 1,340 & $8.7 \%(8.3 \%, 9.2 \%)$ & & 15,407 & 3,329 & $21.6 \%(21.0 \%, 22.3 \%)$ & \\
\hline $4+$ days & 19,915 & 2,366 & $11.9 \%(11.4 \%, 12.3 \%)$ & & 19,915 & 5,323 & $26.7 \%(26.1 \%, 27.3 \%)$ & \\
\hline Study Period and Days to Transfusion & & & & $<0.0001$ & & & & $<0.0001$ \\
\hline Apr 04 - May 01 ( $<=3$ days $)$ & 1,731 & 232 & $13.4 \%(11.9 \%, 15.1 \%)$ & & 1,731 & 526 & $30.4 \%(28.3 \%, 32.6 \%)$ & \\
\hline Apr 04 - May 01 (4+ days) & 5,259 & 853 & $16.2 \%(15.2 \%, 17.2 \%)$ & & 5,259 & 1,821 & $34.6 \%(33.4 \%, 35.9 \%)$ & \\
\hline May 01 - Jun 04 (<= 3 days $)$ & 6,346 & 659 & $10.4 \%(9.7 \%, 11.2 \%)$ & & 6,346 & 1,452 & $22.9 \%(21.9 \%, 23.9 \%)$ & \\
\hline May 01 - Jun 04 (4+ days) & 8,500 & 1,060 & $12.5 \%(11.8 \%, 13.2 \%)$ & & 8,500 & 2,260 & $26.6 \%(25.7 \%, 27.5 \%)$ & \\
\hline Jun 04 - Jul 04 (<= 3 days) & 7,330 & 449 & $6.1 \%(5.6 \%, 6.7 \%)$ & & 7,330 & 1,351 & $18.4 \%(17.6 \%, 19.3 \%)$ & \\
\hline Jun 04 - Jul 04 (4+ days) & 6,156 & 453 & $7.4 \%(6.7 \%, 8.0 \%)$ & & 6,156 & 1,242 & $20.2 \%(19.2 \%, 21.2 \%)$ & \\
\hline Ortho lgG & & & & 0.0483 & & & & 0.0208 \\
\hline Low & 561 & 77 & $13.7 \%(11.1 \%, 16.8 \%)$ & & 561 & 166 & $29.6 \%(26.0 \%, 33.5 \%)$ & \\
\hline Medium & 2,006 & 233 & $11.6 \%(10.3 \%, 13.1 \%)$ & & 2,006 & 549 & $27.4 \%(25.5 \%, 29.4 \%)$ & \\
\hline High & 515 & 46 & $8.9 \%(6.8 \%, 11.7 \%)$ & & 515 & 115 & $22.3 \%(18.9 \%, 26.1 \%)$ & \\
\hline IgG - Time to Transfusion & & & & 0.0500 & & & & $<0.0001$ \\
\hline$<=3$ days $($ Low $)$ & 190 & 25 & $13.2 \%(9.1 \%, 18.7 \%)$ & & 190 & 48 & $25.3 \%(19.6 \%, 31.9 \%)$ & \\
\hline$<=3$ days (Medium) & 727 & 73 & $10.0 \%(8.1 \%, 12.4 \%)$ & & 727 & 166 & $22.8 \%(19.9 \%, 26.0 \%)$ & \\
\hline$<=3$ days (High) & 180 & 11 & $6.1 \%(3.4 \%, 10.6 \%)$ & & 180 & 30 & $16.7 \%(11.9 \%, 22.8 \%)$ & \\
\hline 4+ days (Low) & 371 & 52 & $14.0 \%(10.9 \%, 17.9 \%)$ & & 371 & 118 & $31.8 \%(27.3 \%, 36.7 \%)$ & \\
\hline 4+ days (Medium) & 1,279 & 160 & $12.5 \%(10.8 \%, 14.4 \%)$ & & 1,279 & 383 & $29.9 \%(27.5 \%, 32.5 \%)$ & \\
\hline 4+ days (High) & 335 & 35 & $10.4 \%(7.6 \%, 14.2 \%)$ & & 335 & 85 & $25.4 \%(21.0 \%, 30.3 \%)$ & \\
\hline
\end{tabular}




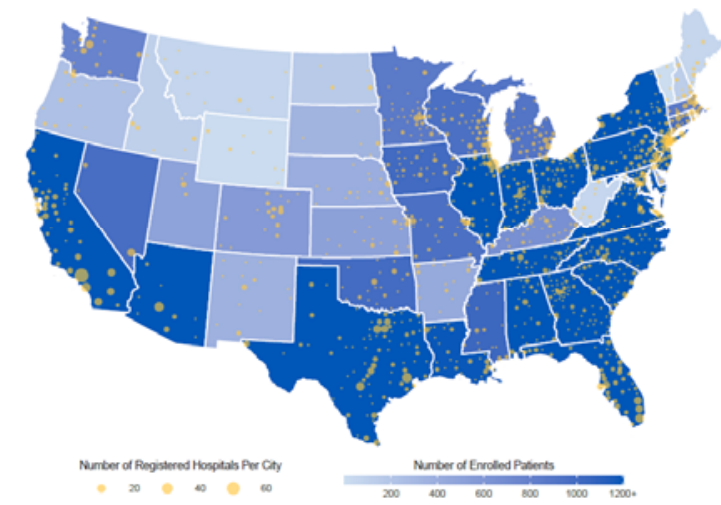

B

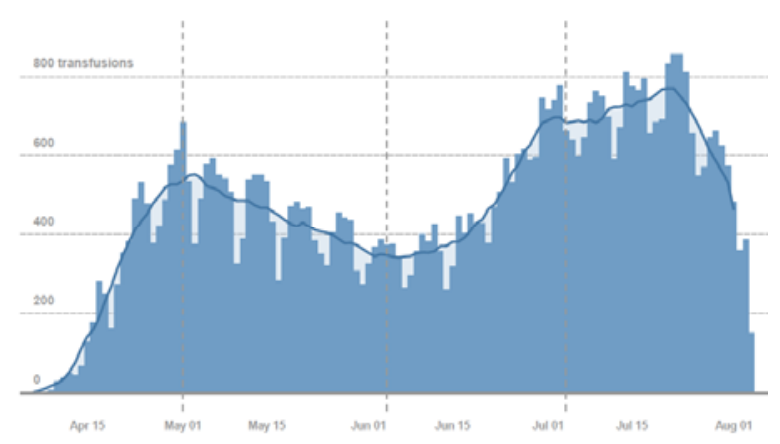

508 Figure 1. Participation in the US COVID-19 Convalescent Plasma Expanded Access

509 Program (EAP). A. Choropleth map displaying the number of cumulatively enrolled patients in

510 the EAP within each state of the contiguous US, with lower enrollment values displayed in a

511 lighter hue and higher enrollment values displayed in a darker hue of blue. Registered acute

512 care facilities are represented as filled yellow circles, with larger circles indicating greater

513 number of registered facilities within the metropolitan area of a city. The choropleth map does

514 not display data from non-contiguous US locations, including registered facilities in Puerto Rico,

515 Hawaii, Alaska, Guam, and Northern Mariana Islands. B. The chronological graph represents

516 the number of patients that have received a COVID-19 convalescent plasma transfusion,

517 including daily counts (blue bars) and 7-day average (blue line). The dashed vertical reference

518 lines delineate the three study epochs. 

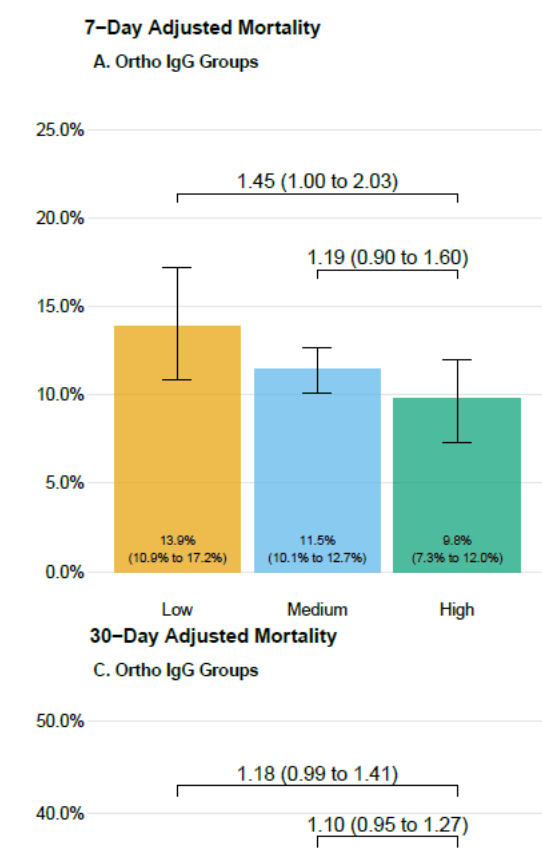

520 Figure 2. Seven day (A, B) and 30-day (C, D) adjusted mortality stratified by antibody 521 groupings in patients transfused with COVID-19 convalescent plasma. Adjusted mortality 522 rate is presented on the vertical axis, and the height of each bar graph represents adjusted 523 mortality with $95 \%$ confidence interval denoted. Data are stratified by groupings of antibody 524 levels with semiquantitative groupings of low (<4.62 S/Co, orange bars), medium (4.62 to 18.45 $525 \mathrm{~S} / \mathrm{Co}$, blue bars) and high (> 18.45 S/Co, green bars). Values presented as text within the boxes 526 are the estimated adjusted mortality rates. Values connecting various categories shown with the 527 overbraces are bootstrapped estimates of relative risk and 95\% bootstrap confidence intervals. 528 Refer to the methods for the variables in the adjustment and the calculation of the relative risks. 
medRxiv preprint doi: https://doi.org/10.1101/2020.08.12.20169359; this version posted August 12, 2020. The copyright holder for this preprint (which was not certified by peer review) is the author/funder, who has granted medRxiv a license to display the preprint in perpetuity.

All rights reserved. No reuse allowed without permission.

\section{A. 7-Day Mortality}

Not ventilaled, no severe risk factors, $\leq 3$ days

$4+$ days

Not ventilaled, limited severe risk factors, $\leq 3$ days

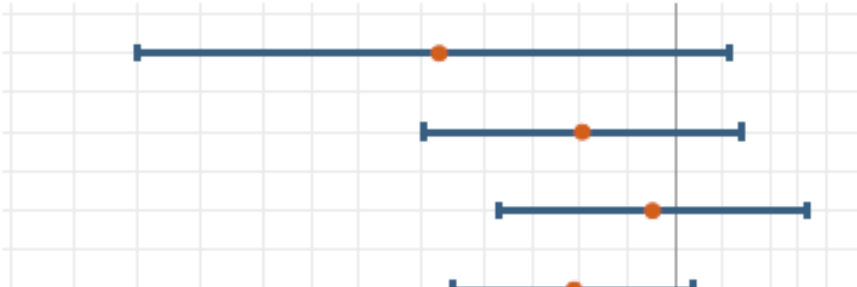

4+ days

Not ventilaled, many severe risk factors, $\leq 3$ days

4+ days

Ventilated, limited severe risk factors, $\leq 3$ days

$4+$ days

Ventlaled, many severe risk factors, $\leq 3$ days

4+ days

Common

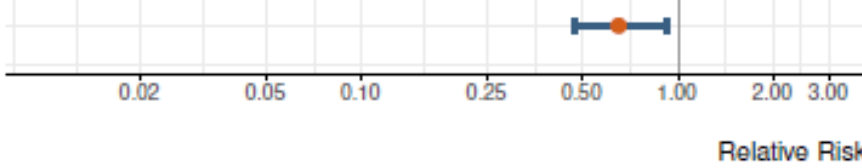

\section{B. 30-Day Mortality}

Not wentilaled, no severe risk factors, $\leq 3$ days

4+ days

Not ventilaled, limiled severe risk factors, $\leq 3$ days

$4+$ days

Not ventilaled, many savere risk factors, $\leq 3$ days

$4+$ days

Ventilaled, limited savere risk factors, $\leq 3$ days

$4+$ days

Ventilaled, many severe risk factors, $\leq 3$ days

4+ days

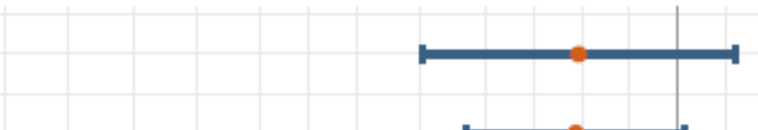

$0.49(0.16,1.52)$

$\mathrm{N}-149$

$0.48(0.22,1.04)$

$\mathrm{N}-167$

$0.86(0.43,1.74)$

$\mathrm{N}-101$

$0.95(0.55,1.62)$

$\mathrm{N}-178$

$0.40(0.09,1.69)$

$\mathrm{N}-43$

$0.28(0.09,0.87)$

$\mathrm{N}-79$

$0.60(0.32,1.12)$

$\mathrm{N}-48$

$1.13(0.82,1.57)$

$\mathrm{N}-180$

$0.56(0.19,1.63)$

$\mathrm{N}-23$

$0.82(0.46,1.47)$

$\mathrm{N}=90$

Common

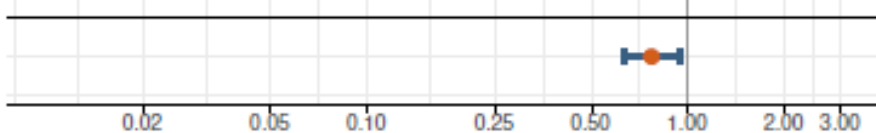

$0.77(0.63,0.94)$ $\mathrm{N}-1,058$ 
medRxiv preprint doi: https://doi.org/10.1101/2020.08.12.20169359; this version posted August 12, 2020. The copyright holder for this preprint (which was not certified by peer review) is the author/funder, who has granted medRxiv a license to display the preprint in perpetuity.

All rights reserved. No reuse allowed without permission.

530 Figure 3. Forest plots of relative risks for 7-day (A) and 30-day (B) mortality for high

531 versus low antibody concentration. Each row in the figure represents 10 mutually exclusive

532 categorizations of patients transfused with convalescent plasma with measured antibody levels.

533 Estimates are the relative risk for mortality for patients who received convalescent plasma with

$534 \mathrm{IgG} \mathrm{S} / \mathrm{co}>18.45$ vs. patients that received < $4.62 \mathrm{~S} /$ Co. Patients that received units with IgG

535 S/Co values between 4.62 and 18.45 are not included in this analysis as the planned

536 comparison was to highlight the potential efficacy of high lgG containing units vs. units with low

537 levels of detectable antibodies. The bottom row in each figure represents the common (pooled)

538 estimate based on the Mantel-Haenszel estimator. The number of severe risk factors was

539 categorized as none $(n=0)$, limited $(n=1-4)$ or many (5 or more), as defined in Table 1.

540 
medRxiv preprint doi: https://doi.org/10.1101/2020.08.12.20169359; this version posted August 12, 2020. The copyright holder for this preprint (which was not certified by peer review) is the author/funder, who has granted medRxiv a license to display the preprint in perpetuity. All rights reserved. No reuse allowed without permission.

Supplement 1

\section{1 | Study Objectives}

544 Convalescent plasma is a potential disease altering therapy for hospitalized patients with COVID-19 infections. There is strong historical precedence for its use in respiratory infections suggesting it may be effective in the treatment of COVID-19. Additionally, the administration of convalescent plasma is considered well-tolerated and safe, both historically and within the context of the current COVID-19 pandemic.

\section{2 | Primary Objectives}

550 The primary outcome of this Expanded Access Program was to provide access to 551 COVID-19 convalescent plasma, assessed as the availability of convalescent plasma.

\section{3 | Secondary Objectives}

553 The secondary outcome of this Expanded Access Program was to determine the safety 554 of transfusion of COVID-19 convalescent plasma assessed as the case-rate and 555 relatedness of serious adverse events.

\section{4 | Tertiary Objectives}

The tertiary outcome of this Expanded Access Program was to explore the efficacy of transfusion of COVID-19 convalescent plasma.

\section{2 | Study Intervention}

This Expanded Access Program was a national, pragmatic intervention conducted as a multicenter, open-label protocol in hospitalized adults with COVID-19. All patients received the study intervention (COVID-19 convalescent plasma transfusion). Primary study endpoints included:

1. Hospital discharge

2. Death

3. 30 days of observation after COVID-19 convalescent plasma transfusion

572 For practical purposes in the current outbreak, one - two units of compatible COVID-19 convalescent plasma were administered. Convalescent plasma was obtained from a registered or licensed blood collector and was collected preferably by apheresis or, if necessary, by conventional methods. Individual institutional guidelines for the administration of plasma were followed, including the use of any premedications, such

\subsection{Study Intervention Description}

Compatible COVID-19 convalescent plasma was administered intravenously according to accepted transfusion guidelines used for fresh frozen plasma.

\section{2 | Dosing and Administration}

as acetaminophen or diphenhydramine. 
medRxiv preprint doi: https://doi.org/10.1101/2020.08.12.20169359; this version posted August 12, 2020. The copyright holder for this preprint (which was not certified by peer review) is the author/funder, who has granted medRxiv a license to display the preprint in perpetuity.

All rights reserved. No reuse allowed without permission.

\section{3 | Preparation and Packaging}

579 Compatible convalescent plasma units were obtained from a registered or licensed 580 blood collector following registration of a patient under the auspices of the Expanded 581 Access Program. COVID-19 convalescent plasma was supplied as an investigational 582 blood product for the treatment of COVID-19. The plasma container label of the COVID58319 convalescent plasma unit included the following statement, "Caution: New Drug 584 Limited by Federal (or United States) law to investigational use." (21 CFR 312.6(a)).

\section{3 | Research Population}

586 Eligible patients for this Expanded Access Program were identified by their treating 587 providers. The patient inclusion criteria were specific to hospitalized patients, these 588 criteria were exceptionally broad.

\section{$589 \quad 3.1 \mid$ Inclusion Criteria}

\section{Supplemental Table 1. Inclusion Criteria}

1. Age at least 18 years

2. Laboratory confirmed diagnosis of infection with SARS-CoV-2

3. Admitted to an acute care facility for the treatment of COVID-19 complications

4. Severe or life threatening COVID-19, or judged by the treating provider to be at high risk of

4. progression to severe or life-threatening disease

5. Informed consent provided by the patient or healthcare proxy

Severe or Life-threatening COVID-19 is defined by one or more of the following:

\section{dyspnea}

respiratory frequency $\geq 30 \cdot \mathrm{min}^{-1}$

blood oxygen saturation $\leq 93 \%$

partial pressure of arterial oxygen to fraction of inspired oxygen ratio $<300$

lung infiltrates $>50 \%$ within 24 to 48 hours

respiratory failure

septic shock

multiple organ failure

\section{$591 \quad 3.2 \mid$ Exclusion Criteria}

592 None. 
medRxiv preprint doi: https://doi.org/10.1101/2020.08.12.20169359; this version posted August 12, 2020. The copyright holder for this preprint (which was not certified by peer review) is the author/funder, who has granted medRxiv a license to display the preprint in perpetuity.

All rights reserved. No reuse allowed without permission.

\begin{tabular}{|c|c|c|c|c|c|}
\hline & Low $(\mathrm{N}=561)$ & $\begin{array}{c}\text { Medium } \\
(\mathrm{N}=2,006)\end{array}$ & High $(N=515)$ & $\begin{array}{l}\text { Total Patients } \\
(\mathrm{N}=3,082)\end{array}$ & $P$ value \\
\hline $\begin{array}{l}\text { Age at Enrollment } \\
\text { (years) }\end{array}$ & & & & & 0.078 \\
\hline 18 to 39 & $59(10.5 \%)$ & $155(7.7 \%)$ & $53(10.3 \%)$ & $267(8.7 \%)$ & \\
\hline 40 to 59 & 185 (33.0\%) & 689 (34.3\%) & $183(35.5 \%)$ & 1,057 (34.3\%) & \\
\hline 60 to 69 & $152(27.1 \%)$ & $503(25.1 \%)$ & $143(27.8 \%)$ & 798 (25.9\%) & \\
\hline 70 to 79 & $102(18.2 \%)$ & $418(20.8 \%)$ & $86(16.7 \%)$ & 606 (19.7\%) & \\
\hline 80 or older & $63(11.2 \%)$ & $241(12.0 \%)$ & $50(9.7 \%)$ & $354(11.5 \%)$ & \\
\hline Gender & & & & & 0.14 \\
\hline Female & $201(36.0 \%)$ & $774(38.7 \%)$ & $221(42.9 \%)$ & 1,196 (38.9\%) & \\
\hline Male & 357 (63.9\%) & $1,227(61.3 \%)$ & 293 (56.9\%) & $1,877(61.0 \%)$ & \\
\hline Undisclosed & $1(0.2 \%)$ & $1(0.0 \%)$ & $1(0.2 \%)$ & $3(0.1 \%)$ & \\
\hline Weight Status & & & & & 0.064 \\
\hline Underweight & $7(1.4 \%)$ & $32(1.7 \%)$ & $3(0.6 \%)$ & $42(1.5 \%)$ & \\
\hline Normal Weight & 87 (17.0\%) & 334 (17.7\%) & $84(17.1 \%)$ & 505 (17.5\%) & \\
\hline Overweight & $154(30.1 \%)$ & 545 (28.8\%) & 115 (23.5\%) & $814(28.1 \%)$ & \\
\hline Obese & $263(51.5 \%)$ & $980(51.8 \%)$ & $288(58.8 \%)$ & $1,531(52.9 \%)$ & \\
\hline Race & & & & & 0.54 \\
\hline White & $266(47.4 \%)$ & $967(48.2 \%)$ & $234(45.4 \%)$ & $1,467(47.6 \%)$ & \\
\hline Asian & $23(4.1 \%)$ & 77 (3.8\%) & $15(2.9 \%)$ & $115(3.7 \%)$ & \\
\hline $\begin{array}{l}\text { Black or African } \\
\text { American }\end{array}$ & $125(22.3 \%)$ & $443(22.1 \%)$ & 135 (26.2\%) & 703 (22.8\%) & \\
\hline Other or Unknown & $147(26.2 \%)$ & 519 (25.9\%) & 131 (25.4\%) & 797 (25.9\%) & \\
\hline Ethnicity & & & & & 0.24 \\
\hline Hispanic/Latino & $223(39.8 \%)$ & $747(37.2 \%)$ & 179 (34.8\%) & $1,149(37.3 \%)$ & \\
\hline Not Hispanic/Latino & $338(60.2 \%)$ & $1,259(62.8 \%)$ & $336(65.2 \%)$ & $1,933(62.7 \%)$ & \\
\hline \multicolumn{6}{|l|}{ Severe Risk Factors } \\
\hline $\begin{array}{l}\text { Current severe or } \\
\text { life-threatening } \\
\text { COVID-19 }\end{array}$ & $382(68.1 \%)$ & $1,286(64.1 \%)$ & 341 (66.2\%) & $2,009(65.2 \%)$ & 0.19 \\
\hline $\begin{array}{l}\text { Intensive Care Unit } \\
\text { (ICU) care prior to } \\
\text { infusion }\end{array}$ & 344 (61.3\%) & $1,226(61.1 \%)$ & 298 (57.9\%) & $1,868(60.6 \%)$ & 0.38 \\
\hline $\begin{array}{l}\text { Mechanical } \\
\text { Ventilation prior to } \\
\text { infusion }\end{array}$ & $183(33.4 \%)$ & 666 (33.9\%) & $158(31.0 \%)$ & 1,007 (33.3\%) & 0.45 \\
\hline \multicolumn{6}{|l|}{ Clinical symptoms $^{\mathrm{a}}$} \\
\hline Respiratory failure & $265(69.4 \%)$ & 919 (71.5\%) & $231(67.7 \%)$ & $1,415(70.4 \%)$ & 0.36 \\
\hline Dyspnea & 265 (69.4\%) & 910 (70.8\%) & 241 (70.7\%) & $1,416(70.5 \%)$ & 0.87 \\
\hline $\begin{array}{l}\text { Blood oxygen } \\
\text { saturation } \leq 93 \%\end{array}$ & 269 (70.4\%) & 909 (70.7\%) & $233(68.3 \%)$ & $1,411(70.2 \%)$ & 0.70 \\
\hline $\begin{array}{l}\text { Lung infiltrates > } \\
50 \% \text { within } 24 \text { to } 48 \\
\text { hours }\end{array}$ & 194 (50.8\%) & $588(45.7 \%)$ & 147 (43.1\%) & 929 (46.2\%) & 0.097 \\
\hline $\begin{array}{l}\text { Respiratory } \\
\text { frequency } \geq 30 / \mathrm{min}\end{array}$ & 177 (46.3\%) & $580(45.1 \%)$ & $157(46.0 \%)$ & 914 (45.5\%) & 0.89 \\
\hline $\begin{array}{l}\mathrm{PaO} 2 \text { :FiO2 ratio < } \\
300\end{array}$ & 137 (35.9\%) & $451(35.1 \%)$ & $93(27.3 \%)$ & $681(33.9 \%)$ & 0.017 \\
\hline
\end{tabular}


medRxiv preprint doi: https://doi.org/10.1101/2020.08.12.20169359; this version posted August 12, 2020. The copyright holder for this preprint (which was not certified by peer review) is the author/funder, who has granted medRxiv a license to display the preprint in perpetuity.

All rights reserved. No reuse allowed without permission.

\begin{tabular}{|c|c|c|c|c|c|}
\hline & Low $(\mathrm{N}=561)$ & $\begin{array}{c}\text { Medium } \\
(\mathrm{N}=2,006)\end{array}$ & High $(\mathrm{N}=515)$ & $\begin{array}{c}\text { Total Patients } \\
(\mathrm{N}=3,082)\end{array}$ & $P$ value \\
\hline $\begin{array}{l}\text { Multiple organ } \\
\text { dysfunction or failure }\end{array}$ & $65(17.0 \%)$ & 227 (17.7\%) & $48(14.1 \%)$ & $340(16.9 \%)$ & 0.29 \\
\hline Septic shock & $56(14.7 \%)$ & $188(14.6 \%)$ & $44(12.9 \%)$ & $288(14.3 \%)$ & 0.71 \\
\hline $\begin{array}{l}\text { Number of Severe Risk } \\
\text { Factors }\end{array}$ & & & & & 0.042 \\
\hline None & $179(31.9 \%)$ & $720(35.9 \%)$ & $174(33.8 \%)$ & $1,073(34.8 \%)$ & \\
\hline Limited (1 to 4 ) & $239(42.6 \%)$ & $868(43.3 \%)$ & $243(47.2 \%)$ & $1,350(43.8 \%)$ & \\
\hline Many $(5+)$ & $143(25.5 \%)$ & $418(20.8 \%)$ & $98(19.0 \%)$ & $659(21.4 \%)$ & \\
\hline \multicolumn{6}{|l|}{$\begin{array}{l}\text { Medications during } \\
\text { hospital stay }\end{array}$} \\
\hline ARB & $27(4.8 \%)$ & $107(5.3 \%)$ & $24(4.7 \%)$ & $158(5.1 \%)$ & 0.77 \\
\hline Ace Inhibitor & $40(7.1 \%)$ & $175(8.7 \%)$ & $35(6.8 \%)$ & $250(8.1 \%)$ & 0.23 \\
\hline Azithromycin & 277 (49.4\%) & $923(46.0 \%)$ & $226(43.9 \%)$ & $1,426(46.3 \%)$ & 0.18 \\
\hline Remdesivir & $164(29.2 \%)$ & $538(26.8 \%)$ & $130(25.2 \%)$ & $832(27.0 \%)$ & 0.32 \\
\hline Steroids & $251(44.7 \%)$ & $899(44.8 \%)$ & 209 (40.6\%) & $1,359(44.1 \%)$ & 0.21 \\
\hline Chloroquine & $4(0.7 \%)$ & $4(0.2 \%)$ & $1(0.2 \%)$ & $9(0.3 \%)$ & 0.12 \\
\hline Hydroxychloroquine & $174(31.0 \%)$ & $595(29.7 \%)$ & $99(19.2 \%)$ & $868(28.2 \%)$ & $<0.001$ \\
\hline Time to Transfusion & & & & & 0.34 \\
\hline 0 days & $16(2.9 \%)$ & $58(2.9 \%)$ & $16(3.1 \%)$ & $90(2.9 \%)$ & \\
\hline 1 to 3 days & $174(31.0 \%)$ & $669(33.3 \%)$ & $164(31.8 \%)$ & $1,007(32.7 \%)$ & \\
\hline 4 to 10 days & $251(44.7 \%)$ & $846(42.2 \%)$ & $244(47.4 \%)$ & $1,341(43.5 \%)$ & \\
\hline $11+$ days & $120(21.4 \%)$ & $433(21.6 \%)$ & $91(17.7 \%)$ & $644(20.9 \%)$ & \\
\hline Time Epoch & & & & & $<0.001$ \\
\hline Apr 04 to May 01 & $146(26.0 \%)$ & $543(27.1 \%)$ & $86(16.7 \%)$ & $775(25.1 \%)$ & \\
\hline May 01 to Jun 04 & $348(62.0 \%)$ & $1,242(61.9 \%)$ & $359(69.7 \%)$ & $1,949(63.2 \%)$ & \\
\hline Jun 04 to Jul 04 & $67(11.9 \%)$ & $221(11.0 \%)$ & $70(13.6 \%)$ & $358(11.6 \%)$ & \\
\hline \multicolumn{6}{|c|}{$\begin{array}{l}\text { These data include a subset of the sample }(n=2,009) \text {, only those patients that currently have severe or life- } \\
\text { threatening COVID-19 } \\
\text { Data was not available for Gender }(n=6) \text {, Weight Status }(n=190) \text { and Mechanical Ventilation prior to infusion ( }\end{array}$} \\
\hline
\end{tabular}


medRxiv preprint doi: https://doi.org/10.1101/2020.08.12.20169359; this version posted August 12, 2020. The copyright holder for this preprint (which was not certified by peer review) is the author/funder, who has granted medRxiv a license to display the preprint in perpetuity.

All rights reserved. No reuse allowed without permission.

Supplemental Table 3. Crude Mortality (7 and 30 day) of patients with IgG transfused with COVID-10 Convalescent Plasma.

\begin{tabular}{|c|c|c|c|c|c|c|c|c|}
\hline & \multicolumn{4}{|c|}{ Seven-day Mortality } & \multicolumn{4}{|c|}{ Thirty-day Mortality } \\
\hline & Sample, No & $\begin{array}{c}\text { Events, } \\
\text { No }\end{array}$ & Estimate, $95 \% \mathrm{Cl}$ & P-value & Sample, No & $\begin{array}{c}\text { Events, } \\
\text { No }\end{array}$ & Estimate, $95 \% \mathrm{Cl}$ & P-value \\
\hline Overall Mortality & 3,082 & 356 & $11.6 \%(10.5 \%, 12.7 \%)$ & & 3,082 & 830 & $26.9 \%(25.4 \%, 28.5 \%)$ & \\
\hline Age & & & & $<0.0001$ & & & & $<0.0001$ \\
\hline $18-39 y$ & 267 & 10 & $3.7 \%(2.0 \%, 6.8 \%)$ & & 267 & 27 & $10.1 \%(7.0 \%, 14.3 \%)$ & \\
\hline $40-59 y$ & 1,057 & 83 & $7.9 \%(6.4 \%, 9.6 \%)$ & & 1,057 & 187 & $17.7 \%(15.5 \%, 20.1 \%)$ & \\
\hline $60-69 y$ & 798 & 89 & $11.2 \%(9.2 \%, 13.5 \%)$ & & 798 & 243 & $30.5 \%(27.4 \%, 33.7 \%)$ & \\
\hline $70-79 y$ & 606 & 97 & $16.0 \%(13.3 \%, 19.1 \%)$ & & 606 & 217 & $35.8 \%(32.1 \%, 39.7 \%)$ & \\
\hline 80 y or older & 354 & 77 & $21.8 \%(17.8 \%, 26.3 \%)$ & & 354 & 156 & $44.1 \%(39.0 \%, 49.3 \%)$ & \\
\hline On Ventilator Prior to Infusion & & & & $<0.0001$ & & & & $<0.0001$ \\
\hline No & 2,014 & 170 & $8.4 \%(7.3 \%, 9.7 \%)$ & & 2,014 & 382 & $19.0 \%(17.3 \%, 20.7 \%)$ & \\
\hline Yes & 1,007 & 177 & $17.6 \%(15.4 \%, 20.0 \%)$ & & 1,007 & 421 & $41.8 \%(38.8 \%, 44.9 \%)$ & \\
\hline Missing & 61 & 9 & $14.8 \%(8.0 \%, 25.7 \%)$ & & 61 & 27 & $44.3 \%(32.5 \%, 56.7 \%)$ & \\
\hline Days to Transfusion & & & & 0.0371 & & & & $<0.0001$ \\
\hline$<=3$ days & 1,097 & 109 & $9.9 \%(8.3 \%, 11.8 \%)$ & & 1,097 & 244 & $22.2 \%(19.9 \%, 24.8 \%)$ & \\
\hline $4+$ days & 1,985 & 247 & $12.4 \%(11.1 \%, 14.0 \%)$ & & 1,985 & 586 & $29.5 \%(27.6 \%, 31.6 \%)$ & \\
\hline Study Period and Days to Transfusion & & & & 0.0470 & & & & $<0.0001$ \\
\hline Apr 04 - May 01 (<= 3 days) & 138 & 14 & $10.1 \%(6.1 \%, 16.3 \%)$ & & 138 & 36 & $26.1 \%(19.5 \%, 34.0 \%)$ & \\
\hline Apr 04 - May 01 (4+ days) & 637 & 95 & $14.9 \%(12.4 \%, 17.9 \%)$ & & 637 & 219 & $34.4 \%(30.8 \%, 38.2 \%)$ & \\
\hline May 01 - Jun 04 (<= 3 days) & 773 & 77 & $10.0 \%(8.0 \%, 12.3 \%)$ & & 773 & 172 & $22.3 \%(19.5 \%, 25.3 \%)$ & \\
\hline May 01 - Jun 04 (4+ days) & 1,176 & 137 & $11.6 \%(9.9 \%, 13.6 \%)$ & & 1,176 & 327 & $27.8 \%(25.3 \%, 30.4 \%)$ & \\
\hline Jun 04 - Jul 04 (<= 3 days) & 186 & 18 & $9.7 \%(6.2 \%, 14.8 \%)$ & & 186 & 36 & $19.4 \%(14.3 \%, 25.6 \%)$ & \\
\hline Jun 04 - Jul 04 (4+ days) & 172 & 15 & $8.7 \%(5.4 \%, 13.9 \%)$ & & 172 & 40 & $23.3 \%(17.6 \%, 30.1 \%)$ & \\
\hline Ortho $\lg G$ & & & & 0.0483 & & & & 0.0208 \\
\hline Low & 561 & 77 & $13.7 \%(11.1 \%, 16.8 \%)$ & & 561 & 166 & $29.6 \%(26.0 \%, 33.5 \%)$ & \\
\hline Medium & 2,006 & 233 & $11.6 \%(10.3 \%, 13.1 \%)$ & & 2,006 & 549 & $27.4 \%(25.5 \%, 29.4 \%)$ & \\
\hline High & 515 & 46 & $8.9 \%(6.8 \%, 11.7 \%)$ & & 515 & 115 & $22.3 \%(18.9 \%, 26.1 \%)$ & \\
\hline IgG - Time to Transfusion & & & & 0.0500 & & & & $<0.0001$ \\
\hline$<=3$ days $($ Low $)$ & 190 & 25 & $13.2 \%(9.1 \%, 18.7 \%)$ & & 190 & 48 & $25.3 \%(19.6 \%, 31.9 \%)$ & \\
\hline$<=3$ days (Medium) & 727 & 73 & $10.0 \%(8.1 \%, 12.4 \%)$ & & 727 & 166 & $22.8 \%(19.9 \%, 26.0 \%)$ & \\
\hline$<=3$ days $($ High $)$ & 180 & 11 & $6.1 \%(3.4 \%, 10.6 \%)$ & & 180 & 30 & $16.7 \%(11.9 \%, 22.8 \%)$ & \\
\hline 4+ days (Low) & 371 & 52 & $14.0 \%(10.9 \%, 17.9 \%)$ & & 371 & 118 & $31.8 \%(27.3 \%, 36.7 \%)$ & \\
\hline 4+ days (Medium) & 1,279 & 160 & $12.5 \%(10.8 \%, 14.4 \%)$ & & 1,279 & 383 & $29.9 \%(27.5 \%, 32.5 \%)$ & \\
\hline 4+ days (High) & 335 & 35 & $10.4 \%(7.6 \%, 14.2 \%)$ & & 335 & 85 & $25.4 \%(21.0 \%, 30.3 \%)$ & \\
\hline
\end{tabular}

596 